\title{
Do Sex Differences in Respiratory Burst Enzyme Activities Exist in Human Immunodeficiency Virus-1 Infection?
}

\author{
Mathias Abiodun Emokpae * and Beatrice Aghogho Mrakpor \\ Department of Medical Laboratory Science, School of Basic Medical Sciences, College of Medical Sciences, \\ University of Benin, Benin 300001, Nigeria; aghoghomrakpor@gmail.com \\ * Correspondence: mathias.emokpae@uniben.edu
}

Academic Editor: Ignacio Martin-Loeches

Received: 5 September 2016; Accepted: 9 November 2016; Published: 15 November 2016

\begin{abstract}
Studies have shown that human immunodeficiency virus type 1 (HIV-1) disproportionally affects more females than males. Affected individuals are susceptible to infections due to depressed immunity, qualitative defects in phagocytic function and altered phagocytosis as well as lowered oxidative burst capacity. This study seeks to determine whether sex differences exist in serum activities of respiratory burst enzymes in HIV-1-infected female and male subjects. Serum myeloperoxidase, catalase and superoxide dismutase activities were assayed in 170 confirmed HIV-1 positive and 50 HIV-1 negative subjects using ELISA. Data were analyzed using Student's $t$-test and $p$ values of less than 0.05 were considered significant. The measured enzyme activities were significantly higher $(p<0.001)$ in females than males in HIV-1 negative subjects while no sex differences were observed in HIV-1 positive subjects. The absence of sex differences in the activities of respiratory burst enzymes in HIV-1 infection may be due to immune activation as a result of active phagocytic leukocytes, immune reactivity and inflammation.
\end{abstract}

Keywords: human immunodeficiency virus type 1; respiratory burst enzymes; sex differences

\section{Introduction}

Human immunodeficiency virus type 1 (HIV-1) infection is a global health challenge that disproportionally affects more females than males [1]. Studies have shown that about $60 \%$ of all subjects with HIV-1 infection are women, especially in sub-Saharan Africa [2]. Apart from social and political factors, biological and genetic dimorphisms have been suggested to be responsible for the differences in disease courses and outcome [3,4]. Following seroconversion after HIV-1 infection, females have $40 \%$ less viral load and more cluster of differentiation $4(\mathrm{CD} 4)^{+}$cells than males [3], but at the same level of viremia, disease severity and progression to acquired immune disease are faster in women [5-8]. Some of the reasons attributed to the sex disparity in HIV-1 infection are increased levels of generalized immune activation [9-11] and elevated inflammatory activity [12,13]. One of the observed disparities in sex differences was innate immunity $[9,12]$. The activity of enzymes in the body can be changed either by their rate of synthesis and secretion from the organ of origin, the distribution in the extracellular compartments or the rate and routes of elimination as well as inactivation [14,15]. These factors may be influenced by individual variability, gender, diseases, drugs or physical activities $[2,9,12]$. These factors are often considered to ensure the appropriate and meaningful use of enzymes in clinical diagnosis and management of patients [14,15].

Respiratory burst enzymes are contributory factors to HIV-1 disease progression $[16,17]$ and are induced by the production of reactive oxygen species (ROS). The deficiency of total antioxidant status might also increase oxidation stress, adversely affecting the immune response and predisposing the 
patient to drug toxicity [18]. Myeloperoxidase (MPO) is an enzyme present in polymorphonuclear leukocytes which performs a vital role in the destruction of phagocytosed microorganisms. MPO activity is directly associated with the activation of phagocytic leukocytes due to invading pathogens which often lead to the destruction of the leukocytes [19]. Respiratory burst refers to the sudden increase in oxygen consumption by reactive oxidants, resulting in the production of hypochlorus acid $(\mathrm{HOCl})$ when cells are invaded by pathogens $[20,21]$. When pathogens are ingested by neutrophils or monocytes, their oxygen consumption increases suddenly. The respiratory burst enzyme (myeloperoxidase) converts hydrogen peroxide $\left(\mathrm{H}_{2} \mathrm{O}_{2}\right)$ to $\mathrm{HOCl}$ in the presence of chloride. The formed $\mathrm{HOCl}$ helps to eliminate phagocytosed pathogens [22]. Studies have indicated that increased susceptibility of HIV-1 infected subjects to bacterial infection may be due to phagocyte dysfunction [23,24]. It has been reported that qualitative defects in phagocytic function in HIV-1 infection can lead to impaired chemotaxis, altered phagocytosis, lowered oxidative burst capacity and altered bacterial killing $[25,26]$, which may exhibit a sex disparity. This is an area of interest for this study which was designed to determine if sex differences exist in the serum activities of respiratory burst enzymes and whether these differences also exist or not in HIV-1 infection.

\section{Patients and Methods}

\subsection{Selection of Study Participants}

The study participants were consecutively enrolled and comprised of 220 subjects that consisted of 120 confirmed HIV-1 positive individuals receiving highly active antiretroviral therapy (HAART) (20 males with mean age of $34.9 \pm 0.6$ years and 100 females with mean age of $33.5 \pm 0.5$ years), 50 newly diagnosed HAART-naive HIV-1 positive subjects ( 24 males with mean age of $32.3 \pm 0.4$ years and 26 females with mean age of $32.1 \pm 0.2$ years) and 50 HIV-1 negative (apparently healthy) individuals recruited from among staff and students of Federal Medical Centre, Yenagoa (controls, 25 males with mean age of $32.6 \pm 0.3$ years and 25 females with mean age of $31.9 \pm 0.4$ years).

\subsection{Inclusion and Exclusion Criteria}

All the confirmed HIV-1 subjects attending the antiretroviral therapy (ART) clinics at the Federal Medical Center, Yenagoa, that gave consent were included in the study. All HIV-1 seronegative individuals who had an illness or infection (chest infections, bacterial endocarditis) or smoke cigarettes that may affect respiratory burst enzymes as well as those who did not give consent were excluded from the study.

\subsection{Ethical Consideration}

The study protocol was reviewed and approved by the Ethics and Research Committee of the Federal Medical Center (ethical code FMC /EC /01/2016, dated 21 ${ }^{\text {st }}$ January, 2016), Yenagoa, Bayelsa State, before the commencement of the study. Informed consent was sought and obtained from all participants and utmost confidentiality of information was maintained.

\subsection{Specimen Collection and Analytical Methods}

Six milliliters of blood sample were collected by venous puncture; $3 \mathrm{~mL}$ were dispensed into a plain tube, while the remaining $3 \mathrm{~mL}$ were emptied into bottles containing ethylene diamine tetra-acetic acid (EDTA). The sample in the plain container was allowed to clot at room temperature. The clotted sample was centrifuged at $3000 \mathrm{rpm}$ for $10 \mathrm{~min}$. The serum was separated into plain containers and stored at $-20^{\circ} \mathrm{C}$ before it was analysed. The serum superoxide dismutase (SOD), catalase (CAT) and MPO were assayed by Enzyme Linked Immunosorbent Assay (ELISA) technique using reagent kits (HS-901811) supplied by Wkea Medical supplies Corp.,Changchun, China. The experiments were done according to the manufacturer's protocol. 
The $\mathrm{CD}^{+}{ }^{+}$count was estimated using Fluorescence Activated Cell Sorter (Facs Flow Cytometer) count system, Lincolnshire, IL, USA.

\subsection{Statistical Analysis}

The data generated from this study were analyzed by the statistical software SPSS version IBM 21 (SPSS Inc., Chicago, IL, USA) for Windows. Categorical variables were compared using Student's $t$-test. A $p$ value $<0.05$ was considered statistically significant.

\section{Results}

Table 1 shows the comparison of respiratory burst enzyme activities in HIV-1 negative male and female subjects. The activities of the measured enzymes were significantly higher $(p<0.001)$ in females.

Table 1. Comparison of respiratory burst enzyme activities between male and female HIV-1 negative subjects.

\begin{tabular}{cccc}
\hline Measured Parameters & $\begin{array}{c}\text { Female } \\
\boldsymbol{n}=\mathbf{2 5}\end{array}$ & $\begin{array}{c}\text { Male } \\
\boldsymbol{n}=\mathbf{2 5}\end{array}$ & $\boldsymbol{p}$ Value \\
\hline $\mathrm{CD}^{+}$cell count $(\mathrm{IU} / \mathrm{mL})$ & $805.1 \pm 9.2$ & $774.6 \pm 6.1$ & $p<0.005$ \\
$\mathrm{CAT}(\mathrm{IU} / \mathrm{L})$ & $12.19 \pm 0.06$ & $10.97 \pm 0.07$ & $p<0.001$ \\
$\mathrm{SOD}(\mathrm{ng} / \mathrm{mL})$ & $1.87 \pm 0.03$ & $1.68 \pm 0.04$ & $p<0.001$ \\
$\mathrm{MPO}(\mathrm{ng} / \mathrm{mL})$ & $10.10 \pm 0.28$ & $8.70 \pm 0.23$ & $p<0.001$ \\
\hline
\end{tabular}

$\mathrm{CD}^{+}$: cluster of differentiation 4; CAT: catalase, SOD: superoxide dismutase, MPO: myeloperoxidase.

Table 2 shows the comparison of respiratory burst enzymes in HIV-1 positive male and female subjects. The activity levels were not statistically significant $(p>0.05)$ between males and females.

Table 2. Comparison of respiratory burst enzymes activities between male and female HIV-1 positive highly active antiretroviral therapy (HAART)-naïve subjects.

\begin{tabular}{cccc}
\hline Measured Parameters & $\begin{array}{c}\text { Female } \\
\boldsymbol{n}=\mathbf{2 6}\end{array}$ & $\begin{array}{c}\text { Male } \\
\boldsymbol{n} \mathbf{2 4}\end{array}$ & $\boldsymbol{p}$ Value \\
\hline $\mathrm{CD}^{+}$cell count $(\mathrm{IU} / \mathrm{mL})$ & $347.4 \pm 17.7$ & $245.7 \pm 9.9$ & $p<0.001$ \\
CAT (IU/L) & $15.44 \pm 0.97$ & $16.74 \pm 1.92$ & $p=0.10$ \\
SOD (ng/mL) & $1.56 \pm 0.022$ & $1.58 \pm 0.045$ & $p=0.50$ \\
$\mathrm{MPO}(\mathrm{ng} / \mathrm{mL})$ & $8.06 \pm 1.01$ & $7.11 \pm 1.72$ & $p=0.50$ \\
\hline
\end{tabular}

Table 3 shows the comparison of respiratory burst enzyme activities in HIV-1 positive male and female subjects on HAART. The levels show no statistically significant difference $(p>0.05)$ between sexes.

Table 3. Comparison of respiratory burst enzymes activities between male and female HIV-1 positive subjects on HAART.

\begin{tabular}{cccc}
\hline Parameters & $\begin{array}{c}\text { Female } \\
\boldsymbol{n}=\mathbf{1 0 0}\end{array}$ & $\begin{array}{c}\text { Male } \\
\boldsymbol{n}=\mathbf{2 0}\end{array}$ & $\boldsymbol{p}$ Value \\
\hline $\mathrm{CD}^{+}$cell count $(\mathrm{IU} / \mathrm{mL})$ & $510.5 \pm 12.7$ & $376 \pm 17.3$ & $p<0.001$ \\
CAT $(\mathrm{IU} / \mathrm{L})$ & $18.24 \pm 1.15$ & $18.44 \pm 2.82$ & $p=0.80$ \\
$\mathrm{SOD}(\mathrm{ng} / \mathrm{mL})$ & $1.49 \pm 0.02$ & $1.45 \pm 0.04$ & $p=0.50$ \\
$\mathrm{MPO}(\mathrm{ng} / \mathrm{mL})$ & $9.67 \pm 1.34$ & $9.50 \pm 2.82$ & $p=0.88$ \\
\hline
\end{tabular}

\section{Discussion}

This study was conducted to determine whether sex differences exist in the activities of respiratory burst enzymes in HIV-1 negative subjects and to know if sex disparity is affected by HIV-1 infection. 
HIV-1 infected subjects are immunocompromised, and prone to opportunistic infections and leukocyte activation as a result of opsonophagocytosis which is actively taking place [27,28]. Sex differences in the activities of respiratory burst enzymes were observed in HIV-1 negative control subjects with activities of MPO (16.1\%), CAT (19.3\%) and SOD $(11.3 \%)$ being higher in women than in men. The observed sex differences are consistent with previous studies [29-32]. These authors also reported that MPO and SOD expression and activity were higher in women than in men. The gender differences in the MPO activity were attributed to higher levels of neutrophils, a cell type rich in MPO. Males were reported to have a lower systemic neutrophil count [29] and lower neutrophil survival than females [30]. Saraymen et al. [33] evaluated the activities of polymorphonuclear leukocyte enzymes in healthy subjects and observed that only SOD activity was significantly higher in females than males, while no sex-dependent correlation between CAT and MPO activities was observed in healthy polymorphonuclear leukocytes, which suggested that CAT and MPO activities were not sex-dependent [33]. The sex differences could also be due to the modulating influence of female sex hormones $[3,4,30]$. Leukocytes use MPO to generate oxidants (ROS) that can initiate lipid peroxidation and oxidation of low density lipoprotein cholesterol (atherogenic form), which are recognized by macrophage scavenger receptors [34]. It was observed that the effects of MPO-generated $\mathrm{HOCl}$ provoked a biphasic response in human endothelial cells (EC) [35]. Whereas low levels of $\mathrm{HOCl}$ $(<10 \mu \mathrm{mol} / \mathrm{L})$ result in EC activation and the generation of tissue factor mRNA, protein and tissue factor pathway activation, higher doses (30-50 $\mu \mathrm{mol} / \mathrm{L})$ provoke EC death by apoptotic mechanisms in which there is rapid caspase 3 activation, a decrease in EC B-cell lymphoma 2 (Bcl-2), cytochrome c release and DNA laddering [34]. In HIV-1 infected subjects, however, there were no sex differences in the measured respiratory burst enzymes. Sex-dependent disparities in the activities of respiratory burst enzymes have been reported in several disease conditions and in drug metabolism, both in human and animal studies [35-41]. Sex differences in the measured enzyme activities were reported in spontaneously hypertensive rats with SOD and CAT significantly higher in males than females. No sex differences were reported in borderline hypertensives and nine-week-old hypertensive Wistar-Kyoto rats [35].

The implication of sex differences in the expression of drug metabolizing and transport genes and disease susceptibility in a sex-dependent fashion has been of interest in health studies [36]. Sex differences in renal angiotensin converting enzyme 2 activity have been reported. Plasma renin activity was observed to be $27 \%$ higher in men than women in normotensive subjects [37]. Sex differences in biology may be due to sex hormone differences that occur during puberty, adulthood and menopause. They could also be due to differences in sex chromosome dosage (2X versus $1 X$ and 0Y versus 1Y) [37]. Other authors using fibroblasts have reported that human $X$-linked genes escape $X$ inactivation fully or partially with only few subsets of these genes that are highly expressed in females [38,39]. Parental imprinting was also suggested to be responsible for sex differences in biology. It may be involved in the potential difference in the effects of XX and XY sex chromosome complements [40]. Whereas the $X$ chromosome in males is only imprinted maternally, the $X$ chromosome in females is imprinted both maternally and paternally. Parental imprinting may impact gene function and bring about pathophysiological consequences $[37,41]$.

The observed sex differences in the activities of respiratory burst enzymes in HIV-1-negative individuals were eliminated in HIV-1 positive subjects both on HAART and not on HAART. Even though women had lower viral loads and higher $\mathrm{CD}^{+}$cell counts during primary infection, they were reported to have a 1.6-fold higher risk of HIV-1 disease progression which ultimately equals the rate observed in men. We hypothesized that the elimination of the sex differences in the respiratory burst enzyme activities may be a contributing factor to disease progression in women. Immune activation has been recognized as a strong predictor for HIV-1 disease progression, which is independent of viral load [2]. Sex disparities in immunological responses to HIV-1 infection may be mediated through genetic variation and the effects of sex hormones [2,42-44], differences in anatomy and sex chromosome-associated factors [1]. The fewer symptoms and delayed diagnoses reported in 
women [45] may be associated with increased activities of respiratory burst enzymes before primary HIV-1 infection. The increase in respiratory burst enzyme activities could be an attempt to combat rapid viral replication in females. The respiratory burst leads to increased oxygen consumption and increased free radical generation which, in turn, leads to an increment of the inflammatory and apoptotic processes. The leakage of toxic substances generated from the activities of respiratory burst enzymes has been reported to damage the nearby cells [19]. In addition, the oxidants produced are toxic, immunosuppressive and have mutagenic effects [46,47]; these factors could contribute to the disease course and outcomes. Sex differences in the Toll-like receptor (TLR) response to HIV infection have been reported. It was suggested that the sex differences in TLR response may largely be responsible for HIV-1 disease progression irrespective of the viral load [2] and CD4 ${ }^{+}$cell counts. The secretion of interferon- $\alpha$ from plasmacytoid dendritic cells via TLR was reported to be significantly higher in women than men [48]. HIV-1 infected females had higher CD4 ${ }^{+}$cell counts than male subjects on HAART and not on HAART. This observation is consistent with previous studies [49,50]. Multivariate linear regression that demonstrated an independent association with sex of both HIV-1 RNA levels and $\mathrm{CD}^{+}$percentages was reported [49]. $\mathrm{CD}^{+}$cell counts were also observed to be higher in adult women with and without HIV-1 infection [50]. It was suggested that intrinsic biological differences in immunologic response to HIV-1 exist between males and females [49]. Our observation has important implications in understanding the biology of the antiviral immune response and possible management strategies.

\section{Conclusions}

The activities of respiratory burst enzymes, which were higher in HIV-1 negative female subjects, were significantly decreased and to equal those of the male counterparts in HIV-1 infection independent of the $\mathrm{CD}^{+}$cell counts. The absence of sex differences in the activities of respiratory burst enzymes may be a reflection of higher immune activation, immune reactivity, inflammation and subsequent differential disease course and outcome in HIV-1 infection in women compared to men.

Acknowledgments: We appreciate the contributions of all staff of the Federal Medical Center, Yenagoa, Bayelsa State, Nigeria. We are grateful to the Medical Laboratory Scientists for their technical support.

Author Contributions: Mathias Abiodun Emokpae conceived, designed the experiments, performed the analysis and wrote the manuscript; Beatrice Aghogho Mrakpor performed the data gathering, analysis and assisted in the writing of the manuscript.

Conflicts of Interest: The authors declare no conflicts of interest.

\section{References}

1. Klein, S.L. Sex influences immune responses to viruses, and efficacy of prophylaxis and treatments for viral diseases. Bioessays 2012, 34, 1050-1059. [CrossRef] [PubMed]

2. Addo, M.M.; Alfred, M. Sex-based differences in HIV-type 1 pathogenesis. J. Infect. Dis. 2014, 209 , S86-S92. [CrossRef] [PubMed]

3. Mann, H.J. Drug-associated disease: Cytochrome P450 interactions. Crit. Care Clin. 2006, 22, 329-345. [CrossRef] [PubMed]

4. Szyf, M. The dynamic epigenome and its implications in toxicology. Toxicol. Sci. 2007, 100, 7-23. [CrossRef] [PubMed]

5. Delmas, M.C.; Jadand, C.; De Vincenzi, I.; Deveau, C.; Persoz, A.; Sobel, A.; Kazatchkine, M.; Brunet, J.B.; Meyer, L. Gender difference in $\mathrm{CD}^{+}$cell counts persist after HIV-1 infection. SEROCO Study Group. AIDS 1997, 11, 1071-1073. [PubMed]

6. Touloumi, G.; Pantazis, N.; Babiker, A.G.; Walker, S.A.; Katsarou, O.; Karafoulidou, A.; Hatzakis, A.; Porter, K.; CASCADE Collaboration. Differences in HIV RNA levels before the initiation of antiretroviral therapy among 1864 individuals with known HIV-1 seroconversion dates. AIDS 2004, 18, 1697-1705. [CrossRef] [PubMed] 
7. Sterling, T.R.; Vlahov, D.; Astemborski, J.; Hoover, D.R.; Margolick, J.B.; Quinn, T.C. Initial plasma HIV-1 RNA levels and progression to AIDS in women and men. N. Engl. J. Med. 2001, 344, 720-345. [CrossRef] [PubMed]

8. Sterling, T.R.; Lyles, C.M.; Vlahov, D.; Astemborski, J.; Margolick, J.B.; Quinn, T.C. Sex differences in longitudinal human immunodeficiency virus type 1 RNA levels among seroconverters. J. Infect. Dis. 1999, 180, 666-672. [CrossRef] [PubMed]

9. Angele, M.K.; Schwacha, M.G.; Ayala, A.; Chaudry, I.H. Effect of gender and sex hormones on immune responses following shock. Shock 2000, 14, 81-90. [CrossRef] [PubMed]

10. Bouman, A.; Schipper, M.; Heineman, M.J.; Faas, M.M. Gender difference in the non-specific and specific immune response in humans. Am. J. Reprod. Immununol. 2004, 52, 19-26. [CrossRef] [PubMed]

11. Deitch, E.A.; Ananthakrishnan, P.; Cohen, D.B.; Xu, D.Z.; Feketeova, E.; Hanser, C.J. Neutrophil activation is modulated by sex hormones after trauma-hemorrhagic shock and burn injuries. Am. J. Physiol. Heart Circ. Physiol. 2006, 291, H1456-H1465. [CrossRef] [PubMed]

12. Diodata, M.D.; Knoferl, M.W.; Schwacha, M.G.; Bland, K.I.; Chaudry, I.H. Gender differences in the inflammatory response and survival following haemorrhage and subsequent sepsis. Cytokine 2001, 14, 162-169. [CrossRef] [PubMed]

13. Imahara, S.D.; Jelacic, S.; Junker, C.E.; O'Keefe, G.E. The influences of gender on human innate immunity. Surgery 2005, 138, 275-282. [CrossRef] [PubMed]

14. Logsdon, C.D.; Li, B. The role of protein synthesis and digestive enzymes in acinar cell injury. Nat. Rev. Gastroenterol. Hepatol. 2013, 10, 362-370. [CrossRef] [PubMed]

15. Schroder, M.; Kaufman, R.J. The mammalian unfold protein response. Annu. Rev. Biochem. 2005, 74, 739-789. [CrossRef] [PubMed]

16. Alimonti, J.B.; Blake, B.T.; Fowke, K.R. Mechanism of $\mathrm{CD}_{4}{ }^{+} \mathrm{T}$ lymphocyte cell death in human immunodeficiency virus infection and AIDS. J. Gen. Virol. 2003, 7, 1649-1661. [CrossRef] [PubMed]

17. Ibeh, B.O.; Eze, S.E.; Habu, J.B. Discordant levels of Superoxide Dismutase and catalase observed in ART Naïve and Experienced HIV patients in south eastern Nigeria. J. Infect. Dis. Ther. 2013, 1, 8-16.

18. Welubo, A.; Smith, P.J. Oxidative stress during antituberculosis therapy in young and elderly patients. Biomed. Environ. Sci. 1995, 8, 106-110.

19. Guven, F.M.K.; Aydin, H.; Yildiz, G.; Engin, A.; Celik, V.K.; Bakir, D.; Deveci, K. The importance of myeloperoxidase enzyme activity in the pathogenesis of Crimean-Congo haemorrhagic fever. J. Med. Microbiol. 2013, 64, 441-445. [CrossRef] [PubMed]

20. Olufunsho, A.; Sunday, O.; Joseph, N.; Titilope, A. Investigation of the levels of oxidative stress parameters in HIV and HIV-TB co-infected patients. J. Infect. Dev. Ctries. 2012, 6, 79-85.

21. Pace, G.W.; Leaf, C.D. The role of oxidative stress in HIV disease. Free Radic. Biol. Med. 1995, 19, 523-528. [CrossRef]

22. Chanock, S.; Saran, M.; Beck-Speier, I.; Fellerhoff, B.; Bauer, G. Phagocytic killing of microorganism by radical processes: Consequences of the reaction of hydroxyl radicals with chloride yielding chlorine atoms. Free Radic. Biol. Med. 1999, 26, 482-490.

23. Roilides, E.; Merlins, S.; Eddy, J.; Walsh, T.J.; Pizzo, P.A.; Rubin, M. Impairment of neutrophil chemotactic and bactericidal function in children infected with human immunodeficiency virus type 1 and partial reversal after in vitro exposure to granulocyte-microphage colony-stimulating factor. J. Pediatr. 1990, 117, 531-540. [CrossRef]

24. Chen, T.P.; Roberts, R.L.; Wu, K.G.; Auk, B.J.; Stiehm, E.R. Decreased superoxide anion and hydrogen peroxide production by neutrophils and monocytes in human immunodeficiency virus-infected children and adults. Pediatr. Res. 1993, 34, 544-550. [CrossRef] [PubMed]

25. Nielsen, H.; Kharazmi, A.; Faber, V. Blood monocyte and neutrophil functions in the acquired immunodeficiency syndrome. Scand. J. Immunol. 1986, 24, 291-296. [CrossRef] [PubMed]

26. Gabrilovich, D.; Ivanova, L.; Serebrovskaya, L.; Shepeleva, G.; Pokrovsky, V. Clinical significance of neutrophil functional activity in HIV infection. Scand. J. Infect. Dis. 1994, 26, 41-47. [CrossRef] [PubMed]

27. Ross, A.C.; Armentrout, R.; O’Riordan, M.A.; Storer, N.; Rizk, N.; Harriu, D.; El-Bejjani, D.; McComsey, G.A. Endothelia activation markers are linked to HIV status and are independent of antiretroviral therapy and lipoatrophy-1. J. Acquir. Immune Defic. Syndr. 2008, 49, 499-506. [CrossRef] [PubMed] 
28. Syed, S.S.; Balluz, R.S.; Kabagambe, E.K.; Meyer, W.A.; Lukas, S.; Wilson, C.M.; Kapogiannis, B.G.; Nachman, S.A.; Sleasman, J.W. Assessment of biomarkers of cardiovascular risk among HIV type 1-infected Adolescents: Roel of soluble vascular cell adhesion molecule as an early indicator of endothelia inflammation. AIDS Res. Hum. Retrovir. 2013, 29, 493-500. [CrossRef] [PubMed]

29. Molloy, E.J.; O’Neil, A.J.; Grantham, J.J.; Sheridan-Pereira, M.; Fitz-Patrick, J.M.; Webb, D.W.; Watson, R.W. Sex-specific alterations in neutrophil apoptosis; the role of estradiol and progesterone. Blood 2003, 102, 2653-2659. [CrossRef] [PubMed]

30. Malorni, W.; Campesi, I.; Straface, E.; Vella, S.; Franconi, F. Redox features of the cell: A gender perspective. Antioxid. Redox Signal. 2007, 9, 1779-1801. [CrossRef] [PubMed]

31. Wassmann, K.; Wassman, S.; Nickenig, G. Progesterone antagonizes the vasoprotective effect of estrogen on antioxidant enzymes expression and function. Circ. Res. 2005, 97, 1046-1054. [CrossRef] [PubMed]

32. Borras, C.; Sastre, J.; Garcia-Sala, D.; Lloret, A.; Pallardo, F.V.; Vina, J. Mitochondrial from females exhibit higher antioxidant gene expression and lower oxidative damage than males. Free Radic. Biol. Med. 2003, 34, 546-552. [CrossRef]

33. Saraymen, R.; Kilic, E.; Yazar, S.; Cetin, M. Influence of sex and age on the activity of antioxidant enzymes of polymorphonuclear leukocytes in healthy subjects. Yonsei Med. J. 2003, 44, 9-14. [CrossRef] [PubMed]

34. Hazen, S.L. Myeloperoxidase and plaque vulnerability. Arterioscler. Thromb. Vasc. Biol. 2004, 24, 1143-1146. [CrossRef] [PubMed]

35. Sugiyama, S.; Kugiyama, K.; Aikawa, M.; Nakamura, S.; Ogawa, H.; Libby, P. Hypochlorous acid, a macrophage product, induces endothelial apoptosis and tissue factor expression. Involvement of myeloperoxidase mediated oxidant in plaque erosion and thrombogenesis. Arterioscler. Thromb. Vasc. Biol. 2004, 24, 1309-1314. [CrossRef] [PubMed]

36. Horvathova, M.; Zitnanova, A.; Kralovicova, Z.; Balis, P.; Puzserova, A.; Muchova, J.; Klukhavsky, M.; Durackova, Z.; Bernatova, I. Sex differences in blood antioxidant defense system in juvenile rats with various genetic predispositions to hypertension. Hypertens. Res. 2016, 39, 64-69. [CrossRef] [PubMed]

37. Yang, L.; Li, Y.; Hong, H.; Chang, C.W.; Guo, L.W.; Lyn-Cook, B.; Shi, L.; Ning, B. Sex differences in the expression of drug metabolizing and transporter genes in human liver. Drug Metab. Toxicol. 2012, 3, 3. [CrossRef]

38. Liu, J.; Ji, H.; Zheng, W.; Wu, X.; Zhu, J.J.; Arnold, A.P.; Sanberg, K. Sex differences in renal angiotensin converting enzyme 2 (ACE2) activity are $17 \beta$-oestradiol-dependent and sex chromosome-independent. Biol. Sex Diff. 2010, 1, 6. [CrossRef] [PubMed]

39. Carrel, L.; Willard, H.F. X-inactivation profile reveals extensive variability in X-linked gene expression in females. Nature 2005, 434, 400-404. [CrossRef] [PubMed]

40. Itoh, Y.; Melamed, E.; Yang, X.; Kampf, K.; Wang, S.; Yehya, N.; Van Nas, A.; Replogle, K.; Band, M.R.; Clayton, D.F.; et al. Dosage compensation is less effective in birds than in mammals. J. Biol. 2007, 6, 2. [CrossRef] [PubMed]

41. Davies, W.; Isles, A.R.; Burgoyne, P.S.; Wilkinson, L.S. X-linked imprinting: Effects on brain and behaviour. Bioessays 2006, 28, 35-44. [CrossRef] [PubMed]

42. McClelland, E.E.; Smith, J.M. Gender specific differences in the immune response to infection. Arch. Immunol. Ther. Exp. (Warsz) 2011, 59, 203-213. [CrossRef] [PubMed]

43. Marriott, I.; Huet-Hudson, Y.M. Sex dimorphism in innate immune responses to infectious organisms. Immunol. Res. 2006, 34, 177-192. [CrossRef]

44. Everhardt Queen, A.; Moerdyk-Schauwecker, M.; Mckee, L.M.; Leamy, L.J.; Huet, Y.M. Differential expression of inflammatory cytokines and stress genes in male and female mice in response to a lipopolysaccharide challenge. PLoS ONE 2016, 11, 1-13. [CrossRef] [PubMed]

45. Cooley, M.; Bakalov, V.; Bondy, C.A. Lipid profiles in women with 45,X vs. 46,XX primary ovarian failure. JAMA 2003, 290, 2127-2128. [CrossRef] [PubMed]

46. Meditz, A.L.; MaWhinney, S.; Allshouse, A.; Feser, W.; Markowitz, M.; Little, S.; Hecht, R.; Daar, E.S.; Collier, A.C.; Margolick, J.; et al. Sex, race, and geographic region influence clinical outcomes following primary HIV-1 infection. J. Infect. Dis. 2011, 203, 442-451. [CrossRef] [PubMed]

47. Valenzuela, A. The biological significance of malondialdehyde determination in the assessment of tissue oxidative stress. Life Sci. 1991, 48, 301-309. [CrossRef] 
48. Beignon, A.S.; McKenna, K.; Skoberne, M.; Manches, O.; DaSilva, I.; Kavanagh, D.G.; Larsson, M.; Gorelick, R.J.; Lifson, J.D.; Bhardwaj, N. Endocytosis of HIV-1 activates plasmacytoid dendritic cells via Toll-like receptor-viral RNA interactions. J. Clin. Investig. 2005, 115, 3265-3275. [CrossRef] [PubMed]

49. Ruel, T.D.; Zanoni, B.C.; Ssewanyana, I.; Cao, H.; Havlir, D.; Kamya, M.; Achan, J.; Charlebois, E.D.; Feeney, M.E. Sex differences in HIV RNA level and CD4 cell percentage during childhood. Clin. Infect. Dis. 2011, 53, 592-599. [CrossRef] [PubMed]

50. Gandhi, M.; Bacchetti, P.; Miotti, P.; Quinn, T.C.; Veronese, P.; Greenblatt, R.M. Does patients sex affect human immunodeficiency virus levels? Clin. Infect. Dis. 2002, 35, 313-322. [CrossRef] [PubMed]

(C) 2016 by the authors; licensee MDPI, Basel, Switzerland. This article is an open access article distributed under the terms and conditions of the Creative Commons Attribution (CC-BY) license (http://creativecommons.org/licenses/by/4.0/). 